\title{
Pengaruh Sumber Karbon pada Produksi Lakase dari Jamur Pelapuk Putih Marasmius sp. dalam Fermentasi Kultur Padat
}

\author{
Hendro Risdianto $^{1}$, Elis Sofianti $^{2}$, Suraya ${ }^{3}$, Sri Harjati Suhardi ${ }^{3}$, Tjandra Setiadi ${ }^{2}$ \\ ${ }^{1}$ Balai Besar Pulp dan Kertas, Jl. Raya Dayeuhkolot No. 132, Bandung, Indonesia \\ ${ }^{2}$ Institut Teknologi Bandung, Jl. Ganesha 10, Gedung Labtek X, Bandung, Indonesia \\ ${ }^{3}$ Sekolah Ilmu dan Teknologi Hayati, Institut Teknologi Bandung, \\ Jl. Ganesha 10, Gedung Labtek XI, Bandung, Indonesia
}

Diterima : 21 Juli 2018, Revisi akhir : 26 Desember 2018, Disetujui terbit : 27 Desember 2018

\section{Influence of Carbon Sources on Laccase Production by White Rot Fungus Marasmius sp. in Solid State Fermentation}

\begin{abstract}
Laccase is one of the ligninolytic enzymes that capable to degrade lignin in biomass. Laccase has been produced by white rot fungus Marasmius sp. in Solid State Fermentation (SSF) using rice straw as the solid support media. The influence of carbon sources, i.e. glucose, glycerol and molasses in medium of laccase production were studied in this paper. The concentration of $0.5 \%, 1.0 \%$ and $2.0 \%$ were used for each carbon sources. The results showed that the highest laccase activity was obtained within 6-10 days of cultivation. Glucose concentration of $0.5 \%, 1.0 \%$ and $2.0 \%$ gave the highest laccase activity were $872.0 \mathrm{U} / \mathrm{L}$ (day 6), $1516.67 \mathrm{U} / \mathrm{L}$ (day 9) and $1270.69 \mathrm{U} / \mathrm{L}$ (day 10), respectively. The highest laccase activity on using glycerol was $1422.36 \mathrm{U} / \mathrm{L}$ (at concentration of $1 \%$ on day $7^{\text {th }}$ ) and $1113.19 \mathrm{U} / \mathrm{L}$ (at concentration of $2 \%$ on day $8^{\text {th }}$ ), respectively. This activity was comparable to that of glucose substrate. Therefore, glycerol and molasses gave a potential chance as carbon sources for laccase production in solid state fermentation.
\end{abstract}

Keywords: glucose, glycerol, laccase, molasses, Marasmius sp., solid state fermentation.

\begin{abstract}
Abstrak
Lakase merupakan salah satu enzim ligninolitik yang memiliki kemampuan mendegradasi lignin. Lakase telah diproduksi menggunakan jamur pelapuk putih Marasmius sp. dalam Fermentasi Kultur Padat (FKP) menggunakan jerami padi sebagai media pertumbuhan. Pengaruh sumber karbon yaitu glukosa, gliserol, dan molase dalam medium produksi lakase digunakan dalam penelitian ini. Konsentrasi 0,5\%; $1,0 \%$; dan $2,0 \%$ digunakan untuk tiap jenis sumber karbon. Hasil menunjukkan bahwa aktivitas tertinggi lakase diperoleh pada kultivasi hari ke 6-10 dengan masing-masing aktivitas (872,0 U/L (hari ke6), $1516,67 \mathrm{U} / \mathrm{L}$ (hari ke-9) dan 1270,69 U/L (hari ke-10). Aktivitas lakase tertinggi diperoleh pada penggunaan medium gliserol dan molase masing-masing adalah 1422,36 U/L (pada konsentrasi 1\%, hari ke-7) dan 113,19 U/L (pada konsentrasi 2\%, hari ke-8). Aktivitas tertinggi tersebut sebanding dengan penggunaan medium glukosa. Oleh karena itu, gliserol dan molase dapat digunakan sebagai alternatif sumber karbon untuk produksi lakase dengan fermentasi kultur padat.
\end{abstract}

Kata kunci: glukosa, gliserol, lakase, molase, Marasmius sp., fermentasi kultur padat 


\section{Pendahuluan}

Lakase (benzenediol:oxygen oxidoreductases, EC 1.10.3.2), merupakan kelompok enzim blue multicopper oxidases (MCO), dan memiliki kemampuan mengkatalisis oksidasi substrat aromatis dan secara bersamaan mereduksi molekul oksigen menjadi air (Muthukumar and Murugan, 2014; Martins et al., 2015). Oleh karena itu, lakase merupakan salah satu enzim yang sangat menjanjikan untuk beberapa proses antara lain pemutihan pulp (Risdianto et al., 2008; Sharma et al., 2014), detoksifikasi efluen (Rezaei et al., 2015), penyisihan senyawa fenol (Asadgol et al., 2014), penghilangan warna limbah tekstil (Forootanfar et al., 2013) dan penyisihan lignin pada proses pembuatan bioetanol dari bahan lignoselulosa (Rencoret et al., 2017). Lakase dapat diproduksi dengan fermentasi kultur rendam (submerged fermentation) dan fermentasi kultur padat (solid state fermentation) (Montoya, Sánchez and Levin, 2014; Bertrand et al., 2015).

Fermentasi kultur padat adalah fermentasi dengan menggunakan mikroorganisme yang ditumbuhkan pada bahan padat dengan ketiadaan atau sedikit air bebas (Pandey, 2003; Soccol et al., 2017). Fermentasi kultur padat merupakan fermentasi yang sesuai untuk produksi enzim oleh jamur berfilamen karena mirip dengan kehidupan alaminya (Couto et al., 2005). Media penyangga untuk fermentasi ini sangat penting, karena keberhasilan proses sangat bergantung terhadap media tersebut. Saat ini, terdapat kecenderungan peningkatan pemanfaatan limbah organik seperti residu agrikultur, kehutanan dan industri yang berkaitan dengan makanan sebagai bahan baku untuk memproduksi enzim dengan teknik fermentasi kultur padat (Osma, Toca Herrera and Rodríguez Couto, 2007). Limbah organik tersebut mengandung lignin dan/atau selulosa dan hemiselulosa yang dapat berguna sebagai induser aktivitas ligninolitik dan membantu produksi lakase lebih ekonomis.

Aplikasi lakase dalam industri dan teknologi lingkungan, termasuk konsep modern integrasi biorefinery memerlukan enzim dalam jumlah besar dan dengan biaya rendah (Elisashvili, Kachlishvili and Penninckx, 2008). Selain penggunaan limbah dari industri agro sebagai media penyangga (Risdianto et al., 2012), penelitian tentang sumber karbon murah juga merupakan salah satu strategi produksi lakase dengan biaya rendah. Beberapa sumber karbon tersebut antara lain molase (Marim et al., 2016) dan gliserol (Li et al., 2011). Molase merupakan hasil samping industri gula tebu, sedangkan gliserol merupakan senyawa kimia yang biasa disebut giserin dan merupakan hasil samping produksi biodiesel melalui tahap transesterifikasi. Peningkatan produksi biodiesel akan menyebabkan produksi gliserol yang melimpah (da Silva, Mack and Contiero, 2009).

Penelitian sebelumnya menunjukkan bahwa Marasmius sp dapat tumbuh dengan baik pada fermentasi kultur padat menggunakan jerami padi dan menghasilkan aktivitas lakase paling baik (Risdianto et al., 2012). Oleh karena itu, penelitian ini bertujuan untuk investigasi sumber karbon alternatif yaitu molase dan gliserol pada produksi lakase menggunakan Marasmius sp. pada fermentasi kultur padat.

\section{Bahan dan Metode}

\section{Bahan Lignoselulosa}

Jerami padi digunakan sebagai media penyangga diperoleh dari lahan pertanian di sekitar Bandung, Indonesia. Jerami dipotong dengan ukuran panjang sekitar $3 \mathrm{~cm}$.

\section{Jamur Pelapuk Putih}

Jamur pelapuk putih Marasmius sp berasal dari laboratorium Mikrobiologi dan Teknologi Bioproses, Program Studi Teknik Kimia, Institut Teknologi Bandung. Jamur ditumbuhkan menggunakan Potato Dextrose Agar (PDA) dalam cawan petri dan diinkubasi selama 7 hari pada suhu $28^{\circ} \mathrm{C}$ dan sebelum digunakan, jamur disimpan pada suhu $4^{\circ} \mathrm{C}$.

\section{Fermentasi Kultur Padat}

Fermentasi kulltur padat dilaksanakan pada suhu ruangan $\left(28 \pm 1^{\circ} \mathrm{C}\right)$. sebanyak 5 gram potongan jerami dimpregnasi dengan $20 \mathrm{~mL}$ medium Kirk termodifikasi dalam labu berukuran $250 \mathrm{~mL}$. Komposisi medium Kirk adalah salah satu sumber karbon (glukosa, gliserol, molase), 1, $\mathrm{g} / \mathrm{L}, \mathrm{MgSO}_{4} .7 \mathrm{H}_{2} \mathrm{O} 0,4 \mathrm{~g} / \mathrm{L}, \mathrm{CaCl}_{2} 0,09 \mathrm{~g} / \mathrm{L}$, sodium asetat $2,3 \mathrm{~g} / \mathrm{L}$, diammonium tartrat $0,4 \mathrm{~g} / \mathrm{L}, \mathrm{MnCl}_{2}$ $0,02 \mathrm{~g} / \mathrm{L}$, ekstrak ragi $0,3 \mathrm{~g} / \mathrm{L}, \mathrm{CuSO}_{4} .7 \mathrm{H}_{2} \mathrm{O} 0,01$ $\mathrm{g} / \mathrm{L}, \mathrm{H}_{2} \mathrm{MoO}_{4} 0,007 \mathrm{~g} / \mathrm{L}, \mathrm{MnSO}_{4} \cdot 4 \mathrm{H}_{2} \mathrm{O} 0,01 \mathrm{~g} / \mathrm{L}$, $\mathrm{ZnSO}_{4}, 7 \mathrm{H}_{2} \mathrm{O} \quad 0,006 \mathrm{~g} / \mathrm{L}$ and $\mathrm{Fe}_{2}\left(\mathrm{SO}_{3}\right)_{3} 0,007$ $\mathrm{g} / \mathrm{L}$. Tiap sumber karbon yang digunakan dalam 
medium Kirk divariasikan konsentrasinya yaitu $0,5 \% ; 1,0 \%$, dan $2,0 \%$. Potongan jerami yang sudah direndam dalam medium Kirk disterilisasi pada suhu $120^{\circ} \mathrm{C}$ selama 20 menit. Setelah steril dan mencapai suhu ruang, inokulum Marasmius sp. dari cawan petri dengan ukuran 1,5 x 1,5 cm sebanyak dua potongan diinokulasikan secara aseptis, dan kultur kemudian diinkubasi pada kondisi statis selama 10 - 13 hari. Contoh diambil setiap 24 jam untuk dianalisis aktivitas lakase. Contoh diekstraksi dengan menambahkan $50 \mathrm{~mL}$ larutan penyangga asetat $(\mathrm{pH} \mathrm{4,5)} \mathrm{dan} \mathrm{digoyang}$ dalam alat penggoyang (shaker) pada $100 \mathrm{rpm}$ selama 2 jam, kemudian ditumbuk dengan mortar. Cairan dari kultur kemudian disentrifugasi pada 5000 rpm selama 10 menit, dan supernatannya digunakan untuk menentukan aktivitas lakase.

\section{Aktivitas Lakase}

Aktivitas lakase ditentukan dengan 2,2'-azino bis (3-ethylbenzthiazoline-6-sulphonic acid) (ABTS) dalam larutan penyangga sodium asetat 0,4 (pH 4.5) (Niku-Paavola et al., 1988). Oksidasi ABTS ditentukan dengan peningkatan absorbansi pada panjang gelombang $420 \mathrm{~nm}\left(\varepsilon_{420}=36(\mathrm{mM}\right.$ $\mathrm{cm}^{-1}$ ) menggunakan spektrofotometer. Satu unit aktivitas (U) didefinisikan sebagai jumlah enzim yang diperlukan untuk mengoksidasi 1 $\mu$ mol ABTS tiap menit pada suhu $28^{\circ} \mathrm{C}$. Semua pengukuran merupakan hasil rata-rata dua kali ulangan.

\section{Produktivitas Lakase}

Produktivitas (U/L/hari) dihitung berdasarkan Persamaan (1)

$$
P_{r}=\frac{U_{0}}{t_{\text {prod }}}
$$

Dengan $P_{r}$ adalah produktivitas (U/L.hari), Uo adalah aktivitas lakase (U/L), dan $t_{\text {prod }}$ adalah waktu fermentasi (hari) (Feijoo, Dosoretz and Lema, 1995).

\section{Hasil dan Pembahasan}

Konsentrasi optimum karbon organik dalam medium pertumbuhan memiliki peran yang penting pada produksi lakase. Jamur basidiomycetes memiliki respon yang berbeda terhadap sumber karbon dan konsentrasinya dalam medium untuk pertumbuhan. Sekresi lakase secara signifikan terjadi saat konsentrasi sumber karbon dalam medium pertumbuhan mencapai tingkat yang rendah (Nadeem, Baig and Sheikh, 2014).

Pada saat menggunakan glukosa sebagai sumber karbon, aktivitas lakase selama fermentasi disajikan pada Gambar 1. Aktivitas tertinggi dicapai pada konsentrasi $1,0 \%$ yaitu $1516,67 \mathrm{U} / \mathrm{L}$ pada hari ke sepuluh. Penggunaan konsentrasi $0,5 \%$ menunjukkan bahwa aktivitas lakase mulai teramati pada hari ke dua $(70,97$ $\mathrm{U} / \mathrm{L}$ ) dan mencapai aktivitas tertinggi pada hari ke

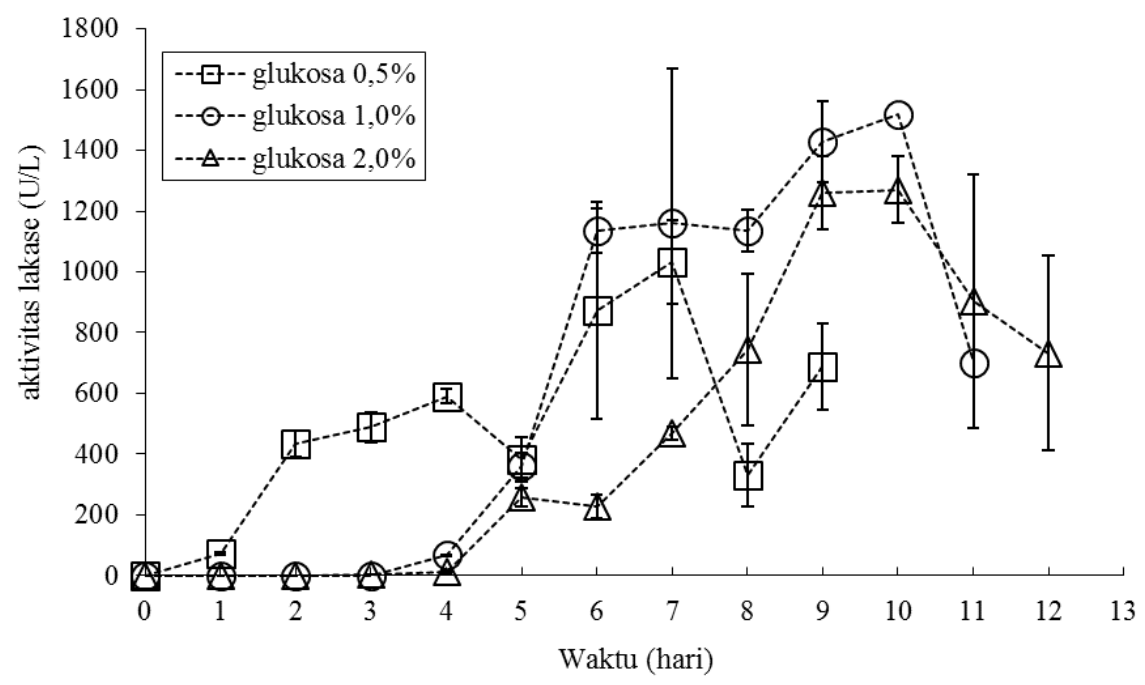

Gambar 1. Aktivitas Lakase menggunakan Sumber Karbon Glukosa 
tujuh (1031,53 U/L) dan kemudian aktivitasnya menurun. Pola yang mirip ditunjukkan pada penggunaan konsentrasi 2,0\%. Aktivitas lakase teramati pertama kali pada hari ke tiga $(4,86 \mathrm{U} / \mathrm{L})$ dan mencapai aktivitas tertinggi sebesar 1270,69 $\mathrm{U} / \mathrm{L}$ pada hari ke sepuluh.

Molase merupakan tetes tebu hasil samping industri gula yang tidak dapat dikristalkan. Molase mengandung gula yang dapat difermentasi sehingga berpotensi sebagai substrat untuk pertumbuhan mikroorganisme (Marim et al., 2016). Gambar 2 menunjukkan aktivitas lakase yang diperoleh pada fermentasi dengan menggunakan molase sebagai sumber karbon. Aktivitas lakase terdeteksi pertama kali pada hari ke empat pada konsentrasi $0,5 \%(159,44 \mathrm{U} / \mathrm{L})$ dan $1,0 \%(113,75 \mathrm{U} / \mathrm{L})$, sedangkan pada konsentrasi $2,0 \%$ aktivitas lakase teramati mulai hari ke lima (31,59\%). Aktivitas tertinggi ditunjukkan pada penggunaan konsentrasi 2,0\% (1113,19 U/L) pada hari ke sembilan. Pada penggunaan konsentrasi $0,5 \%$, lakase mencapai aktivitas maksimum sebesar 722,36 U/L pada hari ke delapan dan sesudahnya menunjukkan aktivitas yang relatif tetap. Aktivitas sebesar 759,31 U/L pada hari ke tujuh merupakan aktivitas tertinggi ketika menggunakan konsentrasi molase 1,0\%.

Produksi lakase dengan menggunakan sumber karbon gliserol disajikan pada Gambar 3. Aktivitas lakase mulai terdeteksi pada hari ke

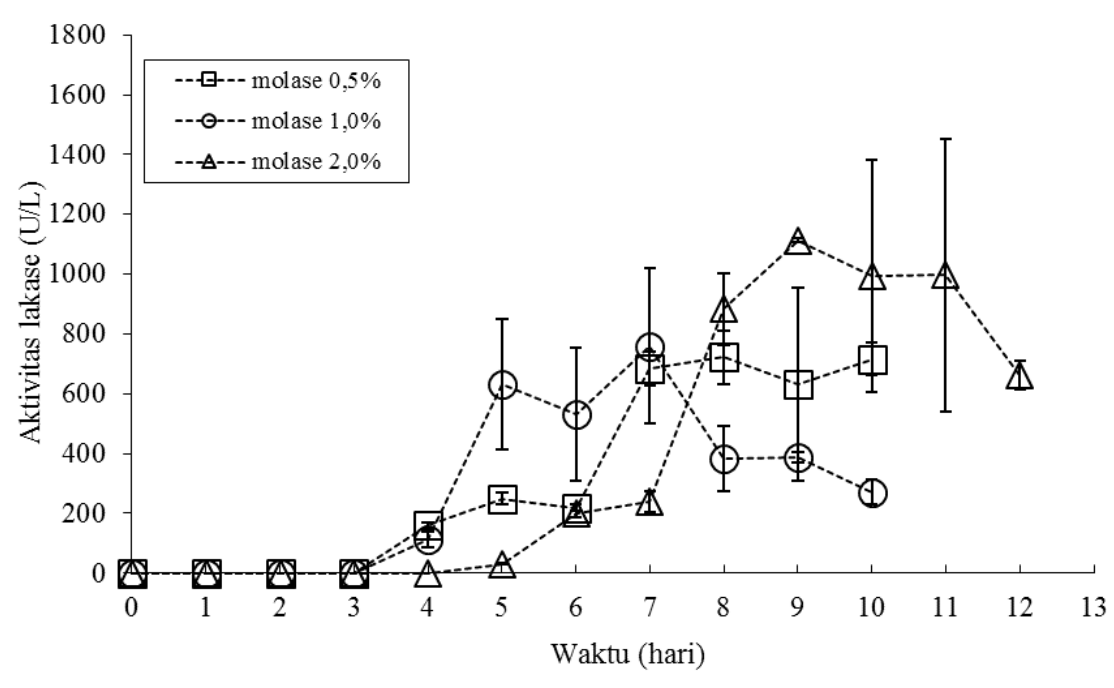

Gambar 2. Aktivitas Lakase menggunakan Molase sebagai Sumber Karbon

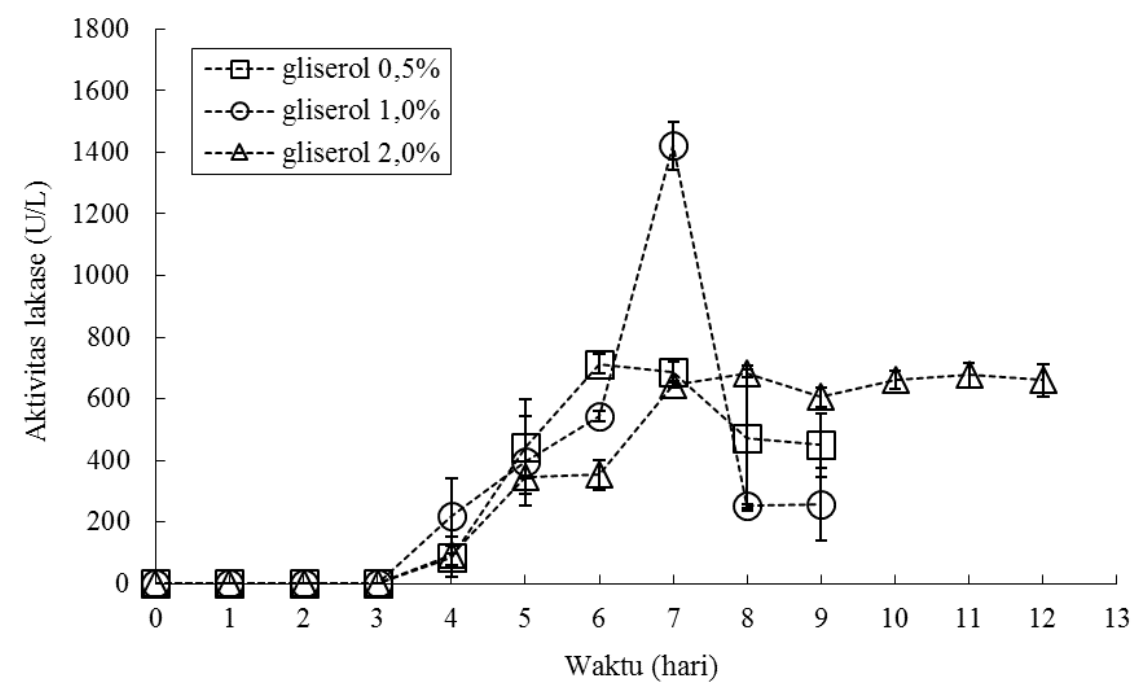

Gambar 3. Aktivitas Lakase menggunakan Gliserol sebagai Sumber Karbon 


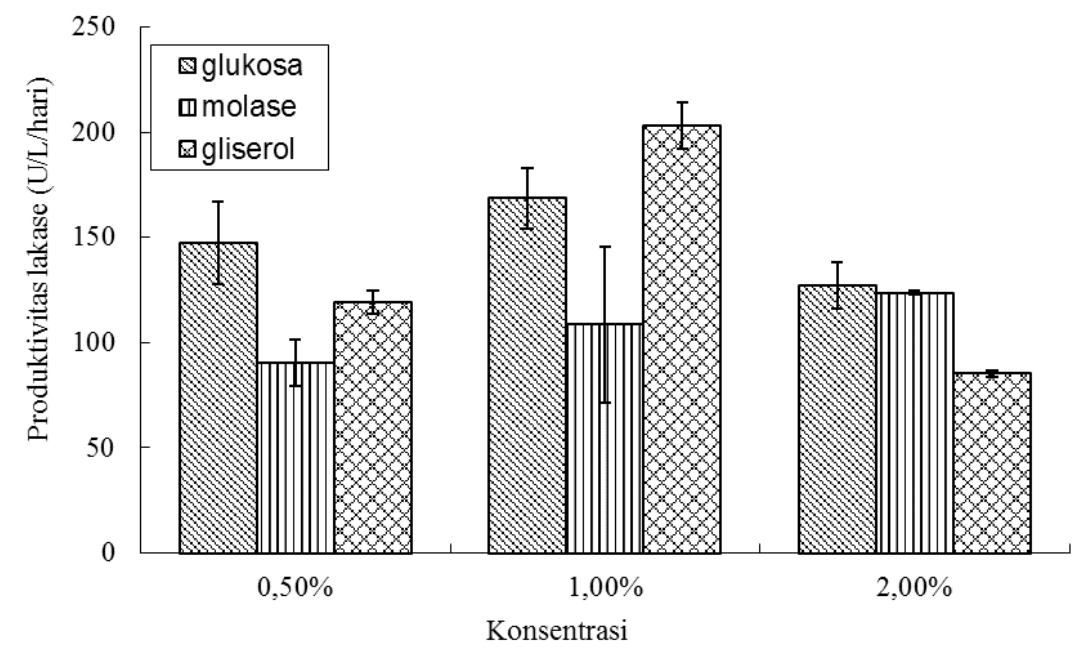

Gambar 4. Perbandingan Produktivitas Maksimum Penggunaan Glukosa, Molase dan Gliserol

empat untuk semua konsentrasi yang digunakan. Aktivitas tertinggi dicapai pada konsentrasi $0,5 \%$ yaitu 713,61 U/L di hari ke 6 dan kemudian aktivitasnya menurun. Pada konsentrasi $1,0 \%$, aktivitas meningkat tajam sampai mencapai aktivitas maksimum sekitar dua kali lipat daripada aktivitas maksimum menggunakan konsentrasi $0,5 \% \quad(1422,36 \mathrm{U} / \mathrm{L})$ pada hari ke tujuh. Aktivitas tertinggi lakase dengan menggunakan konsentrasi 2,0\% lebih rendah dibandingkan dengan konsentrasi $0,5 \%$ dan $1,0 \%$.

Hasil penelitian menunjukkan bahwa aktivitas lakase mulai teramati setelah 2-5 hari kultivasi dan terus meningkat sampai nilai maksimum pada hari ke empat sampai ke enam dan kemudian aktivitasnya menurun. Penurunan ini dapat disebabkan karena degradasi spesifik lakase karena aktivitas protease dalam kultur (Mazumder, Basu and Mukherjee, 2009). Penelitian ini menghasilkan aktivitas tertinggi lakase sekitar $1516 \mathrm{U} / \mathrm{L}$ (penggunaan glukosa dengan konsentrasi 1,0\% pada hari ke sepuluh). Penelitianyang dilakukanolehOsma, TocaHerrera and Rodríguez Couto (2007) menghasilkan lakase dari Trametes pubescens dengan aktivitas tertinggi sebesar $1570 \mathrm{U} / \mathrm{L}$ pada hari ke-20 dengan fermentasi kultur padat dan menggunakan kulit pisang sebagai sumber karbonnya. Sementara itu, Elisashvili, Kachlishvili and Penninckx (2008) dapat menghasilkan aktivitas lebih tinggi (7620 U/L) ketika memproduksi lakase dengan fermentasi yang sejenis untuk jamur Cerena maxima. Penelitian ini menghasilkan aktivitas lakase tertinggi sebesar 1516,67 U/L (hari ke sepuluh dengan konsentrasi glukosa 1,0\%) tanpa menggunakan tambahan induser.

Pada penggunaan glukosa dan gliserol sebagai sumber karbon, peningkatan konsentrasi karbon yang digunakan dalam media fermentasi menghasilkan aktivitas lakase yang semakin tinggi sampai konsentrasi optimum dan kemudian menurun yang dapat diakibatkan karena inhibisi substrat . Kenaikan konsentrasi sumber karbon akan semakin meningkatkan aktivitas lakase terjadi pada penggunaan molase. Hasil ini mengindikasikan bahwa enzim ligninolitik terbentuk sebagai hasil metabolisme sekunder dan dipicu oleh menipisnya sumber nitrogen dan karbohidrat dalam medium (Sánchez, 2009).

Gambar 4 menunjukkan produktivitas lakase saat menggunakan sumber karbon yang berbedabeda. Produktivitas merupakan rasio aktivitas lakase tertinggi dibagi dengan umur kultivasi pada saat menghasilkan aktivitas tertinggi. Glukosa digunakan sebagai kontrol untuk produktivitas lakase yang dihasilkan. Konsentrasi gliserol 1\% menghasilkan produktivitas yang tertinggi $(203,19$ U/L.hari), diikuti dengan produktivitas pada saat menggunakan glukosa 1\% (168.52 U/L.hari).

\section{Kesimpulan}

Marasmius sp. dapat menghasilkan lakase menggunakan sumber karbon glukosa, molase dan gliserol pada media jerami. Produktivitas lakase yang dihasilkan menggunakan sumber karbon gliserol dan molase sebanding dengan sumber karbon glukosa. Oleh karena itu, 
gliserol dan molase memiliki potensi digunakan sebagai sumber karbon untuk produksi lakase. Penggunaan sumber karbon ini merupakan salah satu alternatif untuk produksi lakase dengan biaya rendah.

\section{Daftar Pustaka}

Asadgol, Z. et al. (2014) 'Removal of phenol and bisphenol-a catalyzed by laccase in aqueous solution', Journal of Environmental Health Science and Engineering, 12(1). doi: 10.1186/2052-336X-12-93.

Bertrand, B. et al. (2015) 'Biochemical and molecular characterization of laccase isoforms produced by the white-rot fungus Trametes versicolor under submerged culture conditions', Journal of Molecular Catalysis B: Enzymatic, 122, pp. 339-347. doi: 10.1016/j.molcatb.2015.10.009.

Elisashvili, V., Kachlishvili, E. and Penninckx, M. (2008) 'Effect of growth substrate, method of fermentation, and nitrogen source on lignocellulose-degrading enzymes production by white-rot basidiomycetes', in Journal of Industrial Microbiology and Biotechnology, pp. 1531-1538. doi: 10.1007/ s10295-008-0454-2.

Feijoo, G., Dosoretz, C. and Lema, J. M. (1995) 'Production of lignin peroxidase by Phanerochaete chrysosporium in a packed bed bioreactor operated in semi-continuous mode', Journal of Biotechnology, 42(3), pp. 247-253. doi: 10.1016/01681656(95)00085-5.

Forootanfar, H. et al. (2013) 'Synthetic dye decolorization by three sources of fungal laccase', Research Journal of Chemistry and Environment, 17(5), pp. 76-81. doi: 10.1186/1735-2746-9-27.

Li, P. et al. (2011) 'The effect of carbon source succession on laccase activity in the coculture process of Ganoderma lucidum and a yeast', Enzyme and Microbial Technology, 48(1), pp. 1-6. doi: 10.1016/j. enzmictec.2010.07.005.

Marim, R. A. et al. (2016) 'Use of sugarcane molasses by Pycnoporus sanguineus for the production of laccase for dye decolorization', Genetics and Molecular Research, 15(4), pp. 1-9. doi: 10.4238/gmr15048972.

Martins, L. O. et al. (2015) 'Laccases of prokaryotic origin: enzymes at the interface of protein science and protein technology', Cellular and Molecular Life Sciences, 72(5), pp. 911-922. doi: 10.1007/s00018-0141822-x.
Mazumder, S., Basu, S. K. and Mukherjee, M. (2009) 'Laccase production in solid-state and submerged fermentation by Pleurotus ostreatus', Engineering in Life Sciences, 9(1), pp. 45-52. doi: 10.1002/elsc.200700039.

Montoya, S., Sánchez, Ó. J. and Levin, L. (2014) Mathematical modeling of lignocellulolytic enzyme production from three species of white rot fungi by solid-state fermentation, Advances in Intelligent Systems and Computing. doi: 10.1007/978-3-319-01568252.

Muthukumar, N. P. and Murugan, S. (2014) 'Production, Purification and Application of Bacterial Laccase: A Review', Biotechnology(Faisalabad), 13(5), pp. 196205. doi: 10.3923/biotech.2014.196.205.

Nadeem, A., Baig, S. and Sheikh, N. (2014) 'Mycotechnological production of laccase by Pleurotus ostreatus-P1 and its inhibition study', J. Anim. Plant Sci, 24(2), pp. 492502.

Niku-Paavola, M. L. et al. (1988) 'Ligninolytic enzymes of the white-rot fungus Phlebia radiata.', The Biochemical journal, 254(3), pp. 877-883. doi: 10.1042/bj2540877.

Osma, J. F., Toca Herrera, J. L. and Rodríguez Couto, S. (2007) 'Banana skin: A novel waste for laccase production by Trametes pubescens under solid-state conditions. Application to synthetic dye decolouration', Dyes and Pigments, 75(1), pp. 32-37. doi: 10.1016/j.dyepig.2006.05.021.

Pandey, A. (2003) 'Solid-state fermentation', Biochemical Engineering Journal, 13(2-3), pp. 81-84. doi: 10.1016/S1369703X(02)00121-3.

Rencoret, J. et al. (2017) 'Delignification and Saccharification Enhancement of Sugarcane Byproducts by a Laccase-Based Pretreatment', ACS Sustainable Chemistry and Engineering, 5(8), pp. 7145-7154. doi: 10.1021/acssuschemeng.7b01332.

Rezaei, S. et al. (2015) 'Efficient decolorization and detoxification of reactive orange 7 using laccase isolated from Paraconiothyrium variabile, kinetics and energetics', Journal of the Taiwan Institute of Chemical Engineers, 56, pp. 113-121. doi: 10.1016/j. jtice.2015.04.008.

Risdianto, H. et al. (2008) 'Produksi lakase dan potensi aplikasinya dalam proses pemutihan pulp', Jurnal Selulosa, 43(01), pp. 1-10.

Risdianto, H. et al. (2012) 'Optimisation of laccase production using white rot fungi and agriculture wastes in solid state fermentation', ITB Journal of Engineering Science, 44 B(2). doi: 10.5614/itbj.eng.sci.2012.44.2.1. 
Sánchez, C. (2009) 'Lignocellulosic residues: Biodegradation and bioconversion by fungi', Biotechnology Advances, pp. 185-194. doi: 10.1016/j.biotechadv.2008.11.001.

Sharma, A. et al. (2014) 'Xylanase and laccase based enzymatic kraft pulp bleaching reduces adsorbable organic halogen (AOX) in bleach effluents: A pilot scale study', Bioresource Technology, 169, pp. 96-102. doi: 10.1016/j. biortech.2014.06.066. da Silva, G. P., Mack, M. and Contiero, J. (2009) 'Glycerol: A promising and abundant carbon source for industrial microbiology', Biotechnology Advances, pp. 30-39. doi: 10.1016/j.biotechadv.2008.07.006.

Soccol, C. R. et al. (2017) 'Recent developments and innovations in solid state fermentation', Biotechnology Research and Innovation, pp. 52-71. doi: 10.1016/j.biori.2017.01.002. 
Lurnal Selulosa, Vol. 8, No. 2, Desember 2018: 77 - 84

- Halaman ini sengaja dikosongkan - 